\title{
Integrating Geospatial and Geophysical Information for Deciphering Groundwater Potential Zones in Dudhganga Catchment, Kashmir Valley, India
}

\author{
Haroon Sajjad $^{1, *}$, Mohd Iqbal' ${ }^{2}$ F.A. Bhat ${ }^{3}$ \\ ${ }^{1}$ Department of Geography, Faculty of Natural Sciences, Jamia Millia Islamia, New Delhi, India \\ ${ }^{2}$ Department of Geography, Government Degree College, University of Kashmir, India \\ ${ }^{3}$ Department of Earth Sciences, University of Kashmir, India \\ *Corresponding author: haroon.geog@gmail.com
}

Received February 24, 2014; Revised February 28, 2014; Accepted March 03, 2014

\begin{abstract}
This paper makes an attempt to delineate groundwater potential zones in a catchment by using scientific information of lithology, topography, geophysical characterization and their interrelationship. On the basis of relative contribution of each of thematic layers towards groundwater potential, the weight of each thematic map has been selected. The individual theme weight was multiplied by its respective class weight and then all the raster thematic layers were aggregated in a linear combination equation. Groundwater potential zones map revealed that the plain areas are prospective zones in the catchment and can be helpful in better planning and management of ground resources.
\end{abstract}

\section{Keywords: groundwater potential zones, remote sensing, GIS, Spatial Analyst, Dudhganga catchment}

Cite This Article: Haroon Sajjad, Mohd Iqbal, and F.A. Bhat, "Integrating Geospatial and Geophysical Information for Deciphering Groundwater Potential Zones in Dudhganga Catchment, Kashmir Valley, India.” American Journal of Water Resources, vol. 2, no. 1 (2014): 18-24. doi: 10.12691/ajwr-2-1-3.

\section{Introduction}

The availability of water supply adequate in terms of both quantity and quality is essential to human existence. The rate of withdrawal of groundwater is increasing continuously due to rapid growth of population accompanied by agricultural and industrial development. The demand for water has increased over the years and this has led to water scarcity in many parts of India. The situation is aggravated by the problem of water pollution or contamination. India is heading towards a fresh water crisis mainly due to improper management of water resources and environmental degradation. This situation has resulted into lack of access to safe potable water supply to millions of people. This freshwater crisis is already evident in many parts of India, varying in scale and intensity depending mainly on the time of the year. The occurrence and movement of groundwater in an area is governed by several factors such as topography, lithology, geological structure, depth of weathering, slope, land use/ land cover (LULC) and interrelationship between these factors [1].

The potentiality of geographical information systems (GIS) and remote sensing in groundwater studies are well known $[2,3,4]$. Remote sensing and GIS have proved to be the potential tools for integrating of numerous thematic maps based on topography, geomorphology, land use/ land cover, slope, etc. and producing a conceptual model for deciphering groundwater potential zones [5,6,7]. A systematic integration of these data with follow-up of hydro geological investigation provides rapid and costeffective delineation of groundwater potential zones. Although it has been possible to integrate these data visually and delineate groundwater potential zones, however, it becomes time consuming, difficult, and introduces manual errors [8].

In recent years, many researches were carried out for groundwater exploration and identification of artificial recharge sites using integrated approach of remote sensing and GIS $[9,10,11,12,13]$. [14] used the GIS technique for generation of groundwater prospect zones towards rural development. $[15,16,17,18]$ have used GIS to delineate groundwater potential zone. [19] have applied GIS for processing and interpretation of groundwater quality data. GIS has also been considered for multi criteria analysis in resource evaluation. [20,21,22,23] have carried out groundwater modeling through the use of GIS. [24] have carried out hydrogeomorphological mapping using remote sensing techniques for water resource management around palaeochannels. Many researchers attempted to integrate groundwater controlling features using different type of GIS modeling techniques for groundwater potential mapping in many areas such as $[5,8,12,14,15,18,25-35]$. Weighted index overlay (WIO) is one of the most accepted methods for assigning weights and relative ranks based on the multi criteria evaluations for decision making $[1,18,34,36,37,38]$. Thus, in this study, we attempted to 
utilize the similar method to delineate the potential groundwater zones in Dudhganga watershed.

\section{Study Area}

Dudhganga catchment of Kashmir valley (Figure 1), located in the northern part of India between 330 42' to 340 50' $\mathrm{N}$ and 740 24' to 740 54' E, covers an area of 660 $\mathrm{km}^{2}$. The area supports a varied topography exhibiting altitudinal extremes of 1557 to $4663 \mathrm{~m}$ above mean sea level. The area consists of the lofty Pir-Panjal and flattopped Karewas as foothills and plains. The Pir-Panjal mountain range covers the Kashmir valley on the south and southwest, separating it from the Chenab valley and the Jammu region. The Karewas formation is a unique physiographic feature of this area. These are lacustrine deposits of the Pleistocene age composed of clays, sands, and silts. The soils in the area are generally of three types, viz., loamy soil, Karewas soil and poorly developed mountain soil [39].

Climate of the area is temperate type with warm summers and cold winters. The mean annual temperature is $20^{\circ} \mathrm{C}$. Average annual rainfall in the area is $669 \mathrm{~mm}$ and maximum precipitation occurs during March to April when westerly winds strike the northern face of the PirPanjal Mountains. The geology of the area is quite diverse ranging from Archean to recent; Pir-Panjal represents rocks of a wide range in age. The commonest of the rocks present in the area are Panjal traps, Karewas and alluvium. Drainage of the area is quite significant as most of the drainage flows into river Jhelum. Dudhganga is the important tributaries of river Jhelum which originates near Tatakuti Mountain.

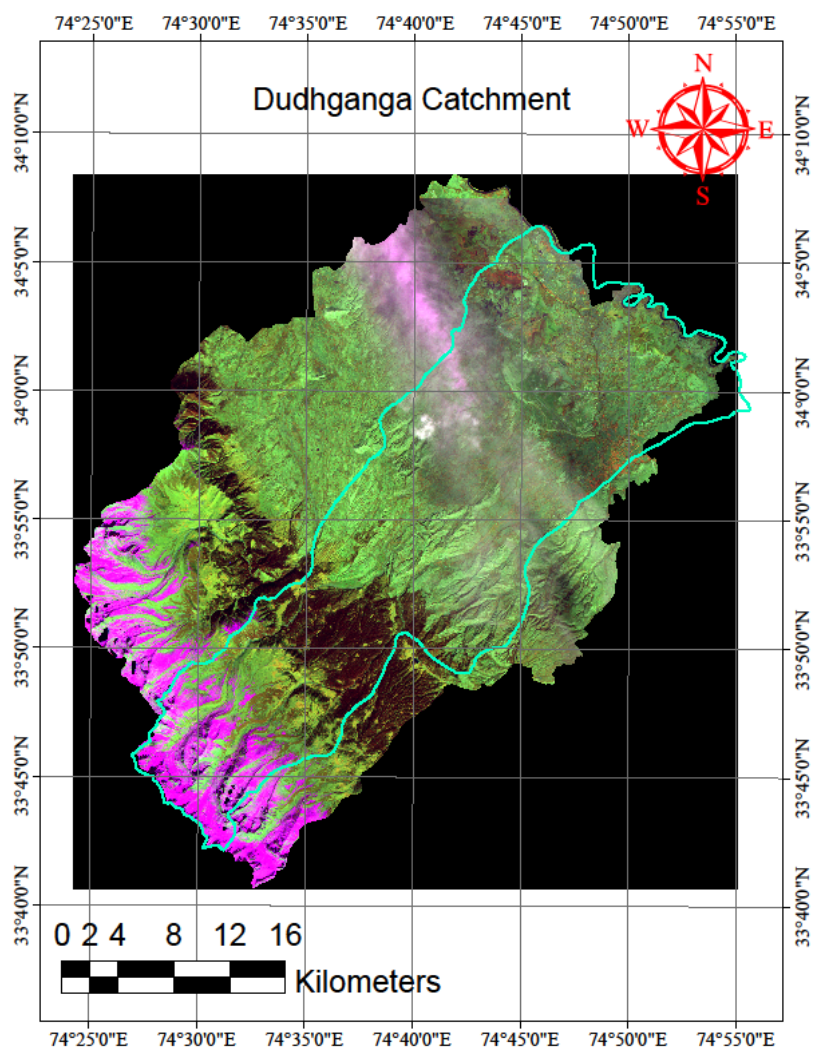

Figure 1. Map of study area

\section{Material and Method}

The Cloud free digital data of Landsat-TM images dated 29 Oct 2010 and Aster DEM were used for the present study. The Survey of Indian top sheet No. 43 K/9 and $43 \mathrm{~K} / 13$ on 1:50000 scales (surveyed on 1961) were used for the preparation of thematic maps. The supervised classification was used to delineate land use/land cover with the help of standard characteristic image interpretation elements like tone, texture, shape, size, pattern, and association followed by field check. The slope, elevation and topography data was extracted from ASTER DEM having resolution of 30 meter. The drainage and lithology data was extracted from digitization of topo sheet and lithology map of Kashmir valley respectively. The thematic maps so prepared were converted into raster form so that they can be easily integrated using GIS. Each of these thematic maps has been assigned suitable weightage factor. These weightage factors have been taken considering the works carried out by researchers such as $[13,15,19]$. These thematic maps were then integrated using "Spatial Analyst" tool of GIS to delineate groundwater potential zones.

Table 1. Assigned Rank and Weightage for Various Thematic Layers

\begin{tabular}{|c|c|c|c|}
\hline Thematic layers & Features/Categories & Rank & Weightage \\
\hline Lithology & $\begin{array}{l}\text { Recent alluvium } \\
\text { Old alluvium } \\
\text { Conglomerates \& Shales } \\
\text { Agglomeratic Slates }\end{array}$ & $\begin{array}{l}1 \\
1 \\
2 \\
2\end{array}$ & 15 \\
\hline Slope & $\begin{array}{l}0-5 \% \\
5-10 \% \\
10-20 \% \\
20-30 \% \\
30-40 \% \\
40-90 \%\end{array}$ & $\begin{array}{l}1 \\
1 \\
2 \\
3 \\
4 \\
4\end{array}$ & 20 \\
\hline Topographyhy & $\begin{array}{l}\text { Canyons, deeply incised } \\
\text { streams } \\
\text { U shaped valleys } \\
\text { Plains } \\
\text { Open slopes } \\
\text { Upper slopes, mesas } \\
\text { Mountain tops, high ridges }\end{array}$ & $\begin{array}{l}4 \\
2 \\
1 \\
3 \\
2 \\
4\end{array}$ & 25 \\
\hline $\begin{array}{l}\text { Land use/ Land } \\
\text { cover }\end{array}$ & $\begin{array}{l}\text { Built up } \\
\text { Agriculture } \\
\text { Forest } \\
\text { Boulder bed } \\
\text { Plantation } \\
\text { Pasture } \\
\text { Scrubland } \\
\text { Wasteland } \\
\text { Snow } \\
\text { Water } \\
\text { Marshy land }\end{array}$ & $\begin{array}{l}4 \\
2 \\
2 \\
3 \\
2 \\
2 \\
2 \\
4 \\
4 \\
1 \\
1\end{array}$ & 15 \\
\hline Drainage density & $\begin{array}{l}\text { Poor } \\
\text { Moderate } \\
\text { Good } \\
\text { Very good }\end{array}$ & $\begin{array}{l}1 \\
2 \\
3 \\
4\end{array}$ & 15 \\
\hline $\begin{array}{l}\text { Elevation } \\
\text { (Meters) }\end{array}$ & $\begin{array}{l}1557-1878 \\
1878-2386 \\
2386-3021 \\
3021-3706 \\
3706-4663\end{array}$ & $\begin{array}{l}1 \\
1 \\
3 \\
4 \\
4\end{array}$ & 10 \\
\hline
\end{tabular}

Weighted index overlay analysis was adopted as a simple mathematical model for a combined analysis of multi parameters. Each thematic map was assigned a weight (Table 1) depending on its influence on the movement and storage of groundwater [29,40,41,42]. Relative ranking of each thematic unit in a theme were 
assigned as knowledge based hierarchy using Spatial Analyst tool of Arc GIS.

The integration of various thematic maps describing favorable groundwater zones into a single groundwater potential map has been carried out through the application of GIS. It required mainly three steps of spatial database building, spatial data analysis and data integration. Spatial data analysis is an analytical technique associated with the study of locations of geographic phenomena together with their spatial dimension and their associated attributes (like table analysis, classification, polygon classification, and weight classification). All thematic maps were reclassified and assigned suitable weightage.

The raster maps of these parameters were assigned respective theme weight and their class weights. The individual theme weight was multiplied by its respective class weight and then all the raster thematic layers were aggregated in a linear combination equation in Arc Map GIS Raster Calculator module as given here:

$$
\begin{aligned}
& \text { Slope } * 20+\text { Drainage density } * 15 \\
& + \text { Lithology } * 15+\text { Topography } * 25 \\
& + \text { Land - use } * 15+\text { Elevation } * 10
\end{aligned}
$$

The resultant map is classified into very good, good, moderate and poor groundwater prospective zones.

\section{Results and Discussion}

\subsection{Lithology}

The rock formation underlying the Dudhganga Catchment ranges from Cambrian to Quaternary (Figure 2).

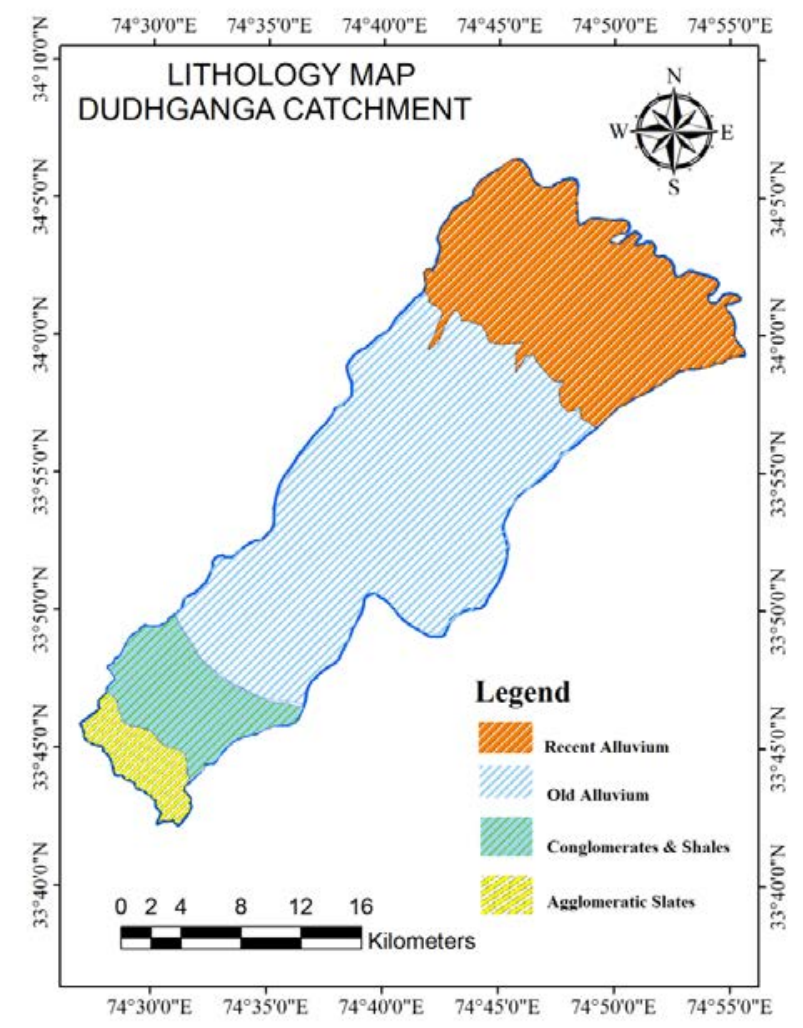

Figure 2. Lithological map of study area

The geological succession of the Dudhganga catchment evolved as Panjal traps forming hilly and mountainous terrain of the study area with hard formations of igneous and metamorphic rocks. The Karewas formation and alluvium of Quaternary and Tertiary age (Plio-Pleistocene) underlie the valley area and consists of alternate bands of sand, silt, gravel \& clay, interspersed at two to three levels locally by glacial boulder beds. This formation is important from groundwater point of view and sustains the water supply system in the area. Areal extent of lithology of the Dudhganga Catchment is shown in Table 2.

Table 2. Lithological units and their areal extent in study area

\begin{tabular}{lcc} 
& \multicolumn{2}{c}{ Area } \\
\cline { 2 - 3 } Lithological units & $\mathrm{Km}^{2}$ & $\%$ \\
\hline Recent alluvium & 201.8 & 30.6 \\
Old alluvium & 363.0 & 55.0 \\
Conglomerates \& Shales & 63.5 & 9.6 \\
Agglomeratic Slates & 31.6 & 4.8 \\
\hline
\end{tabular}

\subsection{Drainage and Drainage Density}

A drainage map of the area gives an idea about the permeability of rocks and also gives an indication of the yield of the basin (Wisler and Brater 1959).

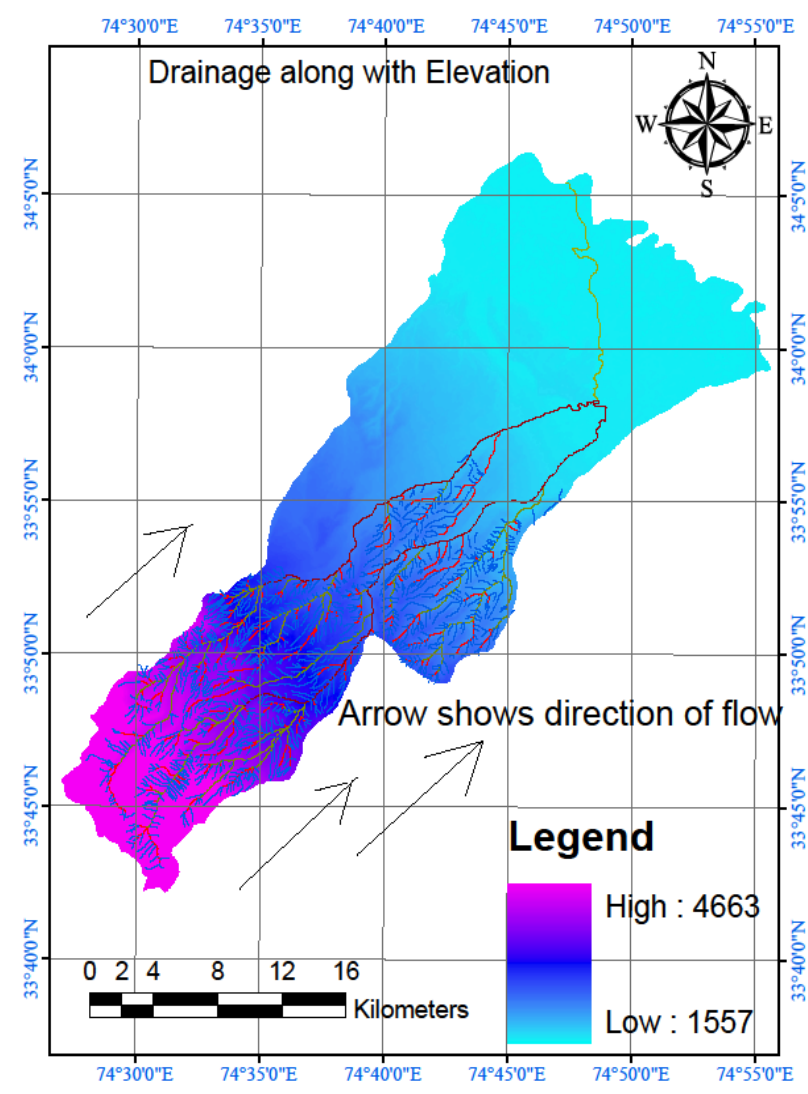

Figure 3. Drainage map of study area

Evaluation of the drainage map (Figure 3) reveals that the catchment is consequent in nature mainly due to the original slope of the land surface. The flow of the direction of tributaries joining the main stream is controlled by structural features. Majority of the lower order streams are found to be in sequent in nature joining the higher order main stream at higher angles and lacking structural and geological controls. The tributaries have spread irregularly in all directions and join the main stream at all angles. 


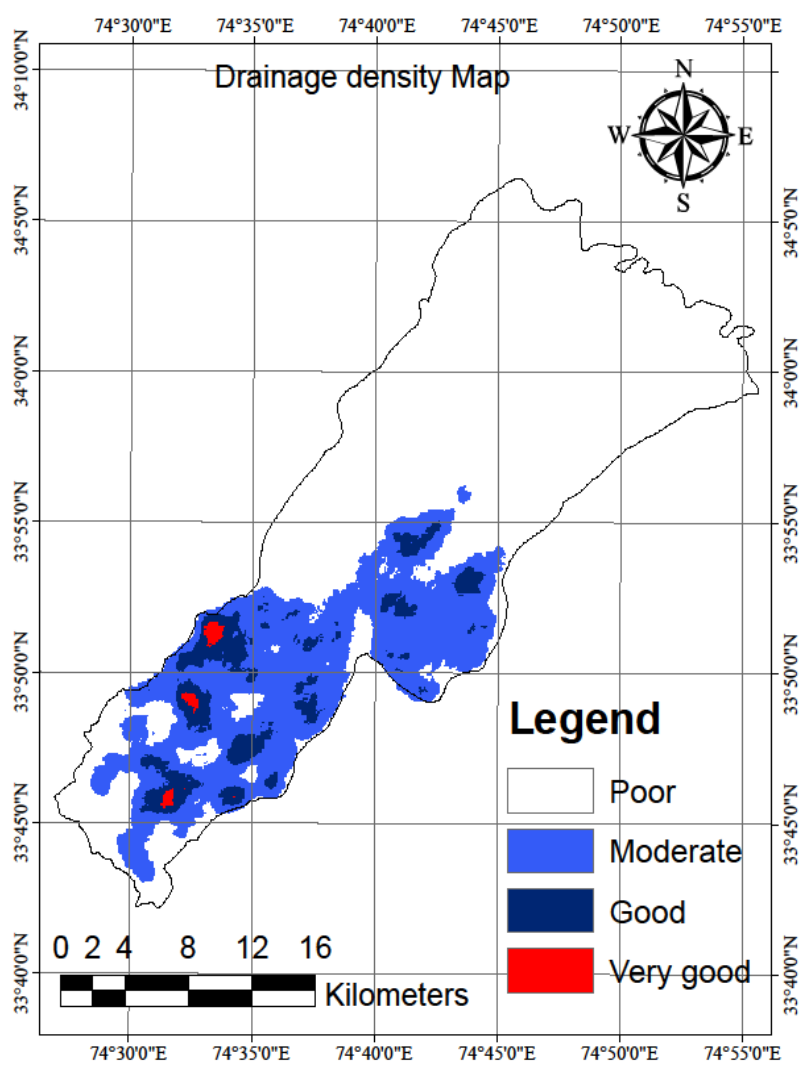

Figure 4. Drainage density map of study area

This suggested the dendritic and sub-dendritic drainage reflecting the homogenous character of the subsurface materials in the Dudhganga catchment. Drainage density is the ratio of the total length of the stream to the area of the drainage basin. The drainage density map was generated from drainage network of the basin using GIS software. High drainage density is an unfavourable site for groundwater existence, moderate drainage density has moderate groundwater potential and less/no drainage density is high groundwater potential zone [44]. Drainage density map of the study area is shown in Figure 4.

\subsection{Slope}

Topography relates to the local and regional relief and gives an idea about the general direction of groundwater flow and its influence on groundwater recharge [7]. Slope of an area represents steepness or inclination of an area determined from two points on a line. Slope plays a vital role in determining soil erosion in hilly terrain. A steep slope will cause more runoff and will enhance the soil erosion in absence of vegetation cover leading to land degradation. The slope percentage map (Figure 5) of the area was generated from the digital elevation model.

Based on the percentage of slope the entire catchment was classified into six categories [45]. Nearly half of the area of catchment is under gentle slope (0-5\%) category. This region of low slope comprised of low lying plains and flat lands and is conterminous with the flood plain of the Jhelum. Table 3 shows that the moderate slope (5-100) region comprises $20.14 \%$ area of the Dudhganga catchment. It mostly encompasses the Karewas lands. It forms a narrow strip of land which covers significant areas along the Pir Panjal flank. The region of moderately steep slope (10-200) covers about $19.61 \%$ of the total area of the catchment. It covers the upper parts of the Karewas and the slopes flanking the mountain girdle.

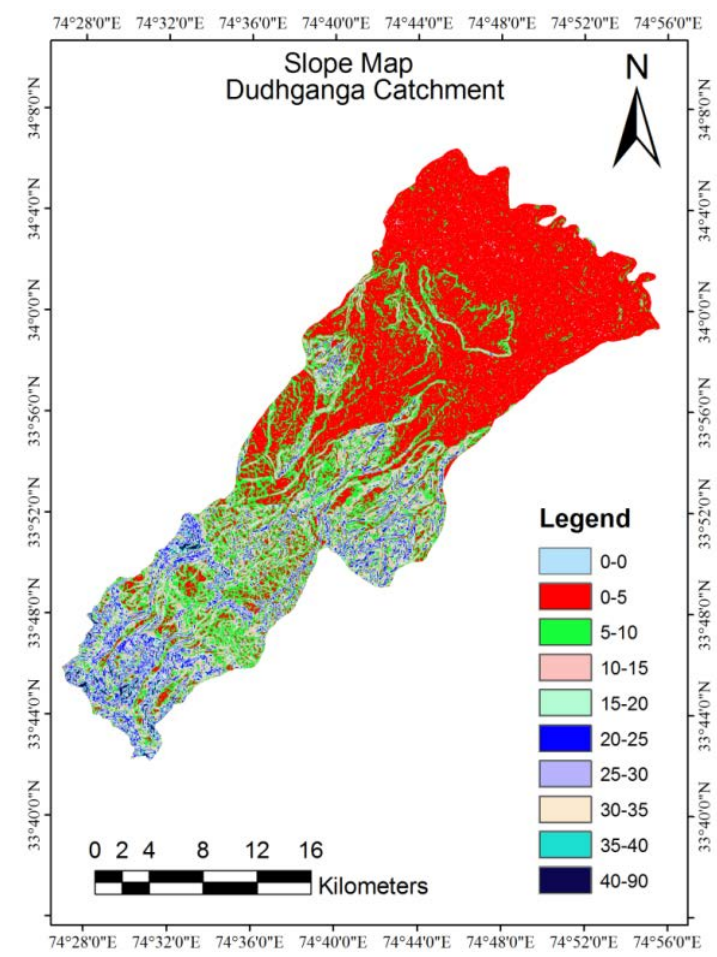

Figure 5. Slope map of study area

Table 3. Slope categories of the catchment

\begin{tabular}{lccc}
\hline \multirow{2}{*}{ Slope category } & \multirow{2}{*}{$\begin{array}{c}\text { Slope } \\
\text { percentage }\end{array}$} & $\mathrm{Km}^{2}$ & $\%$ \\
\cline { 3 - 4 } Gentle & $0-5$ & 334.4 & 50.6 \\
Moderate & $5-10$ & 132.94 & 20.14 \\
Moderately Steep & $10-20$ & 129.46 & 11.57 \\
Steep & $20-30$ & 25.5 & 3.86 \\
Very Steep & $30-40$ & 15.74 & 2.38 \\
Escape Steep & $40-90$ & 2.95 & 0.45 \\
\hline
\end{tabular}

About $7 \%$ area of the catchment is under steep slope (20-300) category. This slope region is partially under thick forest cover and partially under pockets of bare ground and sizable pastures. Very steep slope (30-400) region is highly rugged and dissected by narrow and deep river valleys and is dominated by peaks and scarps. It covers nearly $2.8 \%$ area of the catchment and is too steep to be put to any productive use. The land is almost devoid of any forest cover and remains snow covered for most of the year. The region with slope of above 400 is constituted of escarpment, deep gorges and peaks. This region accounts for $0.45 \%$ of the total area of the catchment. Gentle slope (0-5\%) indicates the presence of high groundwater potential zones, high slope ( $>10 \%)$ shows the presence of poor groundwater potential zones as water runs rapidly off the surface.

\subsection{Topography}

The area is characterized by a dominant plain terrain and a number of erosional and depositional hydro geomorphic features. The topographic map of the basin was prepared using ASTER (DEM) with 30m resolution (Figure 6). 


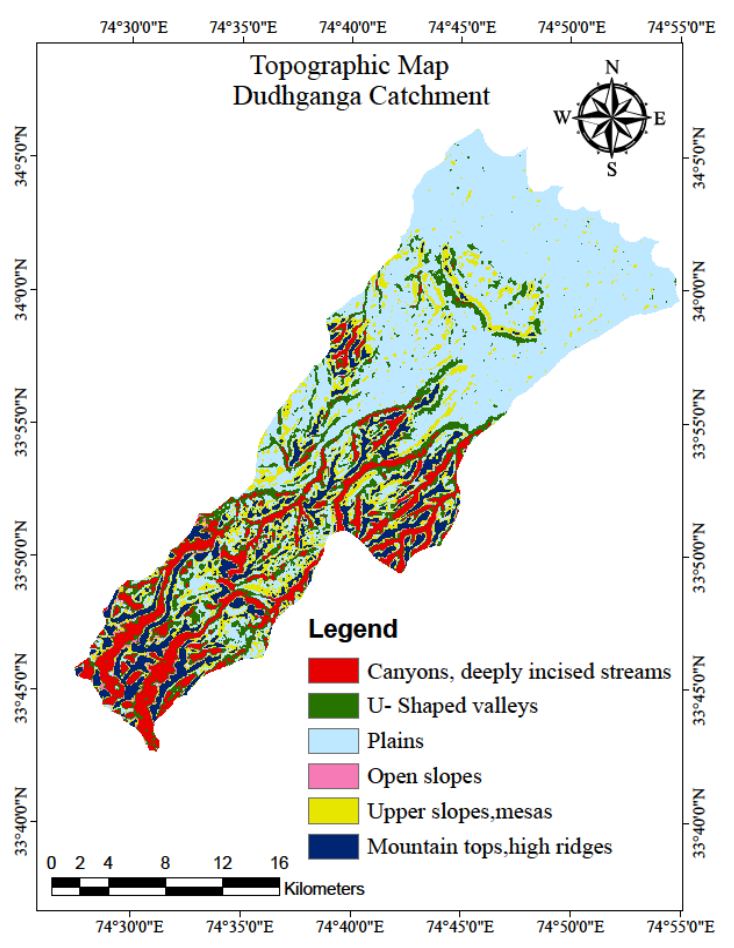

Figure 6. Topographic map of study

Table 4. Topography of Dudhganga catchment

\begin{tabular}{lcc}
\hline \multirow{2}{*}{ Topographic features } & & Area \\
\cline { 2 - 3 } & $\mathrm{Km}^{2}$ & $\%$ \\
\hline Canyons, deeply incised streams & 75.71 & 11.5 \\
U shaped valleys & 102.33 & 15.5 \\
Plains & 315.001 & 47.7 \\
Open slopes & 10.11 & 1.5 \\
Upper slopes, mesas & 85.11 & 12.8 \\
Mountain tops, high ridges & 71.75 & 11.0 \\
\hline
\end{tabular}

Significant topographic units commonly observed on the basis of their image characteristics include canyons, deeply incised streams, U- shaped valleys, plains, open slopes, upper slopes, mesas, mountain tops, high ridges (Table 4).

\subsection{Land Use/ land cover (LULC)}

The LULC of the area provides important indications of the extent of groundwater requirement and utilization (Narendra et al. 2013). The synoptic viewing through remote sensing has provided the multi-spectral data, which has been utilized for classifying LULC. The land use/land cover map (Figure 7) of the entire catchment was generated and the derived statistical data (Table 5) using image processing software.

Table 5. land use/ land cover classes with their areal extent

\begin{tabular}{lcc}
\hline \multirow{2}{*}{ Classes } & \multicolumn{2}{c}{ Area } \\
\cline { 2 - 3 } & Hectares & $\%$ \\
\hline Built up & 7470 & 11.32 \\
Agriculture & 9730 & 14.74 \\
Forest & 6296 & 9.54 \\
Boulder bed & 552.2 & 0.84 \\
Plantation & 17453 & 26.44 \\
Pasture & 4463 & 6.76 \\
Scrubland & 6825 & 10.34 \\
Wasteland & 1953 & 2.96 \\
Snow & 10277 & 15.57 \\
Water & 598.6 & 0.91 \\
Marshy land & 383 & 0.58 \\
\hline
\end{tabular}

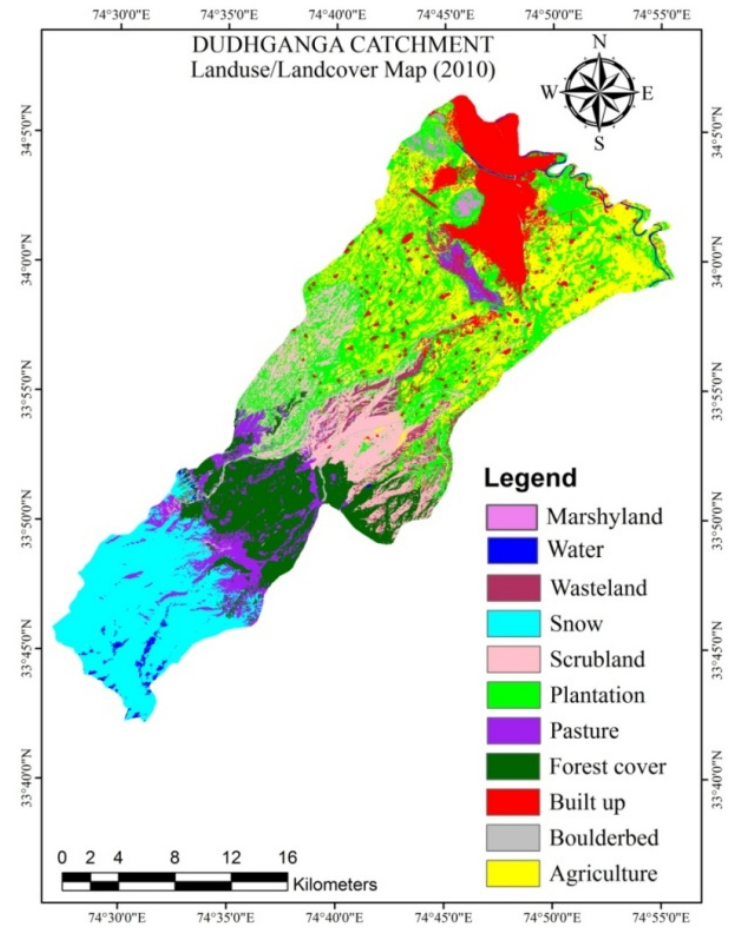

Figure 7. Land use and land cover map of study area

The major land use/land cover classes such as built up land (11.3\%), agriculture (14.7\%), plantation (26.4\%), forest land (9.5\%), scrub land (10\%), pasture (6.7\%), wastelands (2.9\%) and water bodies $(0.9 \%)$ were identified in the study area. From the point of view of land use, agriculture with plantation is an excellent site for groundwater exploration. The area with water bodies is good for groundwater recharge. About $68 \%$ of the catchment area, covered by plantation, agriculture, forest, scrub land and water bodies is favourable for groundwater potential. The detailed weights and ranks are given in Table 1 based on their groundwater prospect zones.

\subsection{Elevation}

Relief directly reflects the terrain ruggedness, which is characterized by the steeper topographic gradient as well as hydraulic gradients the relief increases. The lower relief areas, with elevation $1557 \mathrm{~m}$ to $2386 \mathrm{~m}$ (71.25\%) are characterized by softer lithology permitting more recharge to groundwater, whereas high relief areas, with elevation $3021 \mathrm{~m}$ to $4663 \mathrm{~m}$ elevation comprising only $19.25 \%$ area, have hard and massive rocks forming runoff zone (Table 6).

Table 6. Elevation of Dudhganga catchment

\begin{tabular}{lcc}
\hline \multirow{2}{*}{$\begin{array}{l}\text { Elevation } \\
\text { (Meters) }\end{array}$} & \multicolumn{2}{c}{ Area } \\
\cline { 2 - 3 }$(1557-1878$ & 314.855 & $\%$ \\
$1878-2386$ & 155.406 & 23.70 \\
$2386-3021$ & 62.743 & 9.51 \\
$3021-3706$ & 66.177 & 10.02 \\
$3706-4663$ & 60.87 & 9.22 \\
\hline
\end{tabular}

Based on prior knowledge of the water potential availability and influence exerted by various terrain parameters on movement, accumulation, and yield of groundwater, ranking of various parameters and their subunits has been evolved for groundwater prospects modeling. 


\subsection{Data Integration}

To demarcate the different groundwater prospective zones, all the thematic layers such as lithology, slope, topography, drainage density, land use/ land cover and elevation were integrated through Spatial Analyst in Arc GIS.

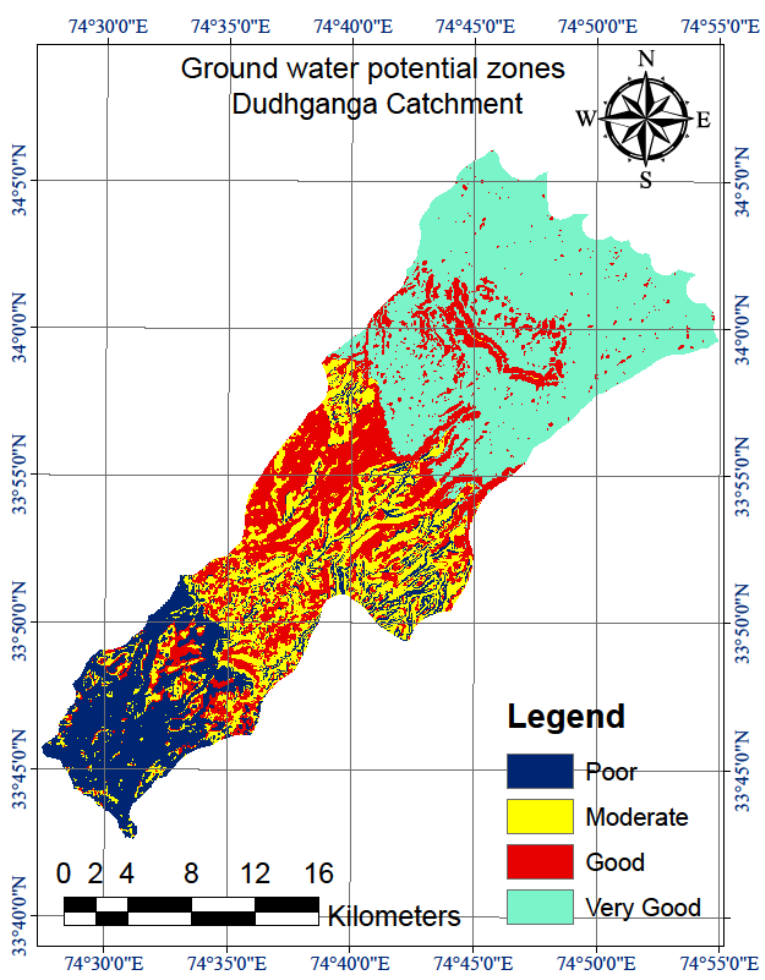

Figure 8. Groundwater potential zones

The raster maps of these parameters were assigned respective theme weight and their class weights. The individual theme weight was multiplied by its respective class weight and then all the raster thematic layers were aggregated in a linear combination equation in Arc Map GIS Raster Calculator module. Groundwater prospective zones map was derived by integrating all the thematic layers such as lithology, drainage density, slope, land use/ land cover through Spatial Analyst in Arc GIS. The groundwater potential map (Figure 8) was generated on the basis of weights and ranks assigned to different features of the thematic layers in GIS, which was classified into groundwater prospect zones based on the decision as very good (63.2\% of the area), good (13\% of the area), moderate (12.8\% of the area) and poor (11.0\% of the area). The map indicates that the plain areas, $U$ shaped valleys are identified as good prospective zones, while, the steep sloping hills underlain by compact lithology and high drainage density are classified as poor prospective areas.

\section{Conclusion}

The mapping of groundwater resources have been increasingly implemented in recent years because of increased demand for water. Remote sensing and GIS have proved to be potential tools for water resources management. They helped in integrating all the data to generate various thematic maps in the study area such as slope, drainage density, lithology, topography, land use/land cover and elevation for preparing water potential map. The geomorphic units viz. plains (47 per cent) are very good prospective zones for groundwater exploration. Presence of low drainage density and low slope indicated occurrence of groundwater. The resultant map of the study revealed that about 15 per cent area of the catchment comes under the category of good groundwater prospective zones, about 13 per cent area consisting of upper slopes comes under the category of moderate groundwater prospective zones while the remaining area comprising of mountain tops, canyons and incised meanders fall in the category of poor water potential zones. The integrated map thus deciphered could be useful for various purposes such as the development of sustainable scheme for groundwater in the area. Thus the integration of GIS and data extracted from satellite images coupled with geophysical data and the geological knowledge of the area under investigation provided a powerful tool in groundwater investigation.

\section{References}

[1] Narendra K, Rao KN, Latha PS (2013) Integrating Remote Sensing and GIS for Identification of Groundwater Prospective Zones in the Narava Basin, Visakhapatnam Region, Andhra Pradesh, Journal Geological Society of India 81:248-260.

[2] Jha MK, Chowdhury A, Chowdary VM, Peiffer S (2007) Groundwater management and development by integrated remote sensing and geographic information systems: prospects and constraints. Water resource management 21:427-467.

[3] Hoffmann J, Sander P (2007) Remote sensing and GIS in hydrogeology. Hydrogeology Journal 15(1):1-3.

[4] Jasmin I, Mallikarjuna P (2011) Review: Satellite-based remote sensing and geographic information systems and their application in the assessment of groundwater potential, with particular reference to India. Hydrogeology Journal 19.

[5] Chowdhury A, Jha MK, Chowdary VM, Mal BC (2009) Integrated remote sensing and GIS-based approach for accessing groundwater potential in West Medinipur district, West Bengal, India. International Journal of Remote Sensing 30(1):231-250.

[6] Murthy KSR (2000) Groundwater potential in a semiarid region of Andhra Pradesh: A geographical information system approach. International Journal of Remote Sensing 21(9): 1867-1884.

[7] Gupta, M, Srivastava PK (2010) Integrating GIS and remote sensing for identification of groundwater potential zones in the hilly terrain of Pavagarh, Gujarat, India. Water Int 35:233-245.

[8] Dar I., Shankar A, Dar MA (2010) Deciphering groundwater potential zones in hard rock terrain using geospatial technology. Environmental Monitoring \& Assessment.

[9] Chatterjee RS, Bhattacharya AK (1995) Delineation of the drainage pattern of a coal basin related inference using satellite remote sensing techniques. Asia Pacific Remote Sensing J 1: 107114.

[10] Teeuw RM (1995) Groundwater exploration using remote sensing and a low-cost geographical information system. Hydrogeology Journal 3:21-30.

[11] Shahid S., \& Nath, S. K. 1999. GIS integration of remote sensing and electrical sounding data for hydrogeological exploration. Journal of Spatial Hydrology, 2(1), 1-12.

[12] Goyal S, Bharawadaj RS, Jugran DK (1999) Multi criteria analysis using GIS for groundwater resource evaluation in Rawasen and Pilli watershed, U.P. http://www.GIS development.net. Cited 17 Dec 2003.

[13] Saraf A, Choudhary PR (1998). Integrated remote sensing and GIS for ground water exploration and identification of artificial recharge site. International Journal of Remote Sensing 19: 18251841.

[14] Jaiswal RK, Mukherjee, S, Krishnamurthy J, Saxena, R (2003) Role of remote sensing and GIS techniques for generation of groundwater prospect zones towards rural development-An approach. International Journal of Remote Sensing 24: 993-1008. 
[15] Krishnamurthy JN, Venkatesa K, Jayaraman V, Manivel M (1996) An approach to demarcate ground water potential zones through remote sensing and geographical information system. International Journal of Remote Sensing 17:1867-1884.

[16] Murthy K.S.R, Mamob AG (2009). Multi-criteria decision evaluation in groundwater zones identification in MoyaleTeltele sub basin, South Ethiopia. Int. Jour. Remote Sensing 30: 27292740.

[17] Obi R, Chandra GP, Mouli K, Srivastav SK, Srinivasan CV, Maji AK (2000) Evaluation of groundwater potential zones using remote sensing data-a case study of Gaimukh watershed, Bhandara district,Maharashtra. Journal of the Indian Society and Remote Sensing 28(1): 1-32.

[18] Pratap K, Ravindran KV, Prabakaran B (2000) Groundwater prospect zoning using remote sensing and geographical information system: A case study in Dala-Renukoot Area, Sonbhadra District Uttar Pradesh. Journal of the Indian Society and Remote Sensing 28(4): 249-263.

[19] Srinivasan RY, Jugran KD (2003) Delineation of groundwater potential zones and zones of groundwater quality suitable for domestic purposes using remote sensing and GIS. Hydrogeology Science Journal 48:821-833.

[20] Shahid, S, Nath SK, Roy J (2000) Ground water potential modeling in soft rock area using GIS. Journal of Remote Sensing 21:1919-1924.

[21] Boutt DF, David WH, Bryan CP, David, T L (2001) Identifying potential land use-derived solute sources to stream base flow using ground water models and GIS. Ground Water 39: 24-34

[22] El-kadi AI, Oloufa AA, Eltahan AA, Malic HU (1994) Use of a geographic information system in site-specific groundwater modeling. Ground Water 32:617-625.

[23] Jacob N, Saibaba J, Prasada RP (1999) Groundwater modeling for sustainable development using GIS techniques. Preconference (Vol. 264-267). Geoinformatics Beyond 2000, Dehradun, India.

[24] Mohammed A, Balasubramanian A, Kondoh A, Rokhmatuloh R, Mustafa, A J (2003) Hydrogeomorphological mapping using remote sensing techniques for water resource management around palaeochannels, geoscience and remote sensing symposium, IGARSS-APOS;03. In: Proceedings of the 2003 IEEE International, Toulouse, France 5: 3317-3319).

[25] Rao BV, Briz-Kishore BH (1991) A methodology for locating potential aquifers in a typical semi-arid region in India using resistivity and hydrogeologic factors. Geoexploration 27: 55-64.

[26] Sarkar B, Deota B, Raju P, Jugran D (2001) A Geographic Information System Approach to evaluation of groundwater potentiality of Shamri Micro-watershed in the Shimla Taluk, Himachal Pradesh. Journal of the 'Indian Society of Remote Sensing 29(3):151-162.

[27] Singh A. K, Raviprakash S, Mishra D, Singh S (2002) Groundwater potential modeling in Chandraprabha subwatershed, U.P. using remote sensing, Geo electrical and GIS. http://www.gisdevelopment.net

[28] Phukon P, Phukan S, Das P, Sarma B (2004) Multicriteria evaluation in GIS environment for groundwater resource mapping in Guwahati city areas, Assam. http:// www.gisdevelopment.net/proceeding/mapindia/.

[29] Nag SK (2005) Application of lineament density and hydrogeomorphology to delineate groundwater potential zones of
Baghmundi block in Purulia district, West Bengal. Journal of the Indian Society of Remote Sensing 33(4): 521-529.

[30] Solomon S, Quiel F (2006) Groundwater study using remote sensing and geographic information systems (GIS) in central highlands of Eritrea. Hydrogeology Journal 14(5):729-741.

[31] Mondal, MS, Pandey AC, Garg RD (2007) Groundwater prospects evaluation based on hydrogeomorphological mapping using high resolution satellite images: a case study in Uttarakhand. Journal of the Indian Society of Remote Sensing 36:69-76.

[32] Rokade VM, Kundal P, Joshi AK (2007) Groundwater potential modeling through remote sensing and GIS: A case study from Rajura Taluka, Chandrapur District, Maharashtra. Journal of the Geological Society 69:943-948.

[33] Madrucci V, Taioli F, Cesar de Araujo C (2008) Groundwater favorability map using GIS multicriteria data analysis on crystalline terrain, Sao Paulo State, Brazil. Journal of Hydrology 357:153-173.

[34] Nagarajan M, Singh S (2009) Assessment of groundwater potential zones using GIS technique. Jour. Indian Soc. Remote Sensing 37:69-77.

[35] Magesh NS, Chandrasekar N, Soundranayagam JP (2012) Delineation of groundwater potential zones in Theni district, Tamil Nadu, using remote sensing, GIS and MIF techniques. Geoscience Frontiers 1-8.

[36] Javed A, Wani, M.H (2009) Delineation of groundwater potential zones in Kakund watershed, Eastern Rajasthan, using remote sensing and GIS techniques. Jour. Geol. Soc. India 73:229-236.

[37] Subba RN (2009) A numerical scheme for groundwater development in a watershed basin of basement terrain: a case study from India. Hydrogeol. Jour 17:379-396.

[38] Jha, M.K, Chowdary V.M, Chowdhury A (2010) Groundwater assessment in Salboni Block, West Bengal (India) using remote sensing, geographical information system and multicriteria decision analysis techniques. Hydrogeol. Jour 18: 1713-1728.

[39] Raza M, Ahmad A, Mohammad A (1978) The Valley of Kashmir: A Geographical Interpretation, New Delhi: Vikas Publishing House, Pvt. Ltd.

[40] Dinesh KPK, Gopinath G, Seralathan P (2007) Application of remote sensing and GIS for the demarcation of groundwater potential zones of a river basin in Kerala, southwest coast of India. Int. Jour. Remote Sensing 28:5583-5601.

[41] Avtar R, Singh CK, Shashtri S, Singh A, Mukherjee S ( 2010) Identification and analysis of groundwater potential zones in KenBetwa river linking area using remote sensing and geographic information system. Geocarto Int 25:379-396.

[42] Preeja KR, Joseph S, Thomas J, Vijith H ( 2011) Identification of groundwater potential zones of a tropical river basin (Kerala, India) using remote sensing and GIS techniques. Jour. Indian Soc. Remote Sensing 39: 83-94.

[43] Wisler, C.O. and Brater, B.F. 1959. Hydrology. New York: Willey

[44] Todd DK, Mays LW (2005) Groundwater Hydrology. 3rd ed., Hoboken: John Wiley \& Sons.

[45] Mukhopadhayay SC (1980) Some techniques and recent trends in Geomorphological Studies in R.B Mandal and V.N.P. Sinha (eds.), Recent trends and concepts in Geography, Concept publishing company, New Delhi 1: 249-84. 